\title{
Innovation projects performance: Analyzing the impact of organizational characteristics
}

\author{
José Ramón Cobo Benita, Enrique Rodríguez Segura, Isabel Ortiz Marcos, Luis Ballesteros Sánchez
}

\begin{abstract}
This study analyzes the effect of organizational characteristics on the innovation project performance. This research applies fuzzy set Qualitative Comparative Analysis (fsQCA) to a large sample of Spanish firms appearing in the Community Innovation survey (CIS). The results show that the combination of organizational innovation, firm size and cooperation with national and, especially, international firms is a sufficient condition for the success of innovation projects within the organization. Evidence also suggests that variables such as the investment on R\&D per employee or the seniority of the company do not affect the success of innovation projects. These findings help complement some results in previous studies on innovation projects performance.
\end{abstract}

\section{Introduction}

A discussion exists among academics and practitioners about the im portance of studying the factors of success and failure of projects exist (Balachandra \& Friar, 1997; Dvir et al., 1998; Ika et al., 2012; Pinto \& Mantel, 1990; Scott Young \& Samson, 2008) Firms design, develop and implement different projects, both internal and external, and their success directly affects significant economic benefits, economic and in tellectual growth for its employees, and important loses that can lead to failure

In the literature, two blocks of investigation aim at highlighting the factors of success and failure of projects within an organization. On one side, some investigations exist about management methodologies using own elaboration surveys as research methods for specific sectors or geographical regions (Bloom \& Van Reenen, 2010; Motohashi, 2005). On the other side, some investigations focus on success and fail ure of projects, building on specific case studies and success criteria about management (Cooke Davies, 2002; Dilts \& Pence, 2006). In addition, several studies analyze in detail the factors that improve organizational innovation (Crossan \& Apaydin, 2010; Damanpour \& Aravind, 2012; Ganter \& Hecker, 2014; García Vega \& López, 2010), but do not link the effect of these factors on the success of innovation projects.

According to several authors (Belso Martínez et al. 2013; Cantner et al., 2011), a greater number of successful innovation projects leads to higher incomes for shareholders and higher learning for their employees
Linking innovation with project based organizations, this study demonstrates the effect of certain organizational characteristics in the success of innovation projects a firm develops.

This study introduces fuzzy set Qualitative Comparative Analysis (fsQCA) to the research on innovation projects and applies this ap proach to a large representative sample of 10,163 Spanish firms FsQCA is suitable for exploring complex relationships among several factors influencing an expected outcome (Cheng et al., 2013; Fiss, 2011; Ragin, 2006) By facilitating that analysis, this approach presents a practical way to organize several interdependent cause effect rela tionships into a framework explaining variance in performance of inno vation projects. Implications to a bigger population are therefore feasible using fsQCA (Woodside, 2013).

The results suggest that no single organizational characteristic is key for ensuring the success of innovation projects, and no particular causal path leads to that outcome. Because of significant interdependencies, the main contributing organizational characteristics to the success of in novation projects within the company relate to organizational innova tion, national and international cooperation, firm size, and holding firm membership

Following this introduction, Section 2 contains the theoretical framework Section 3 describes the method. Section 4 presents research findings Section 5 offers conclusions and further research 


\section{Literature review}

Many diverse factors contribute to success on innovation projects performance. According to Lovallo and Kahneman (2003) more than $70 \%$ of new manufacturing plants in North America close during its first decade of operation. Debacles like that staged the governments of Britain, Germany, Italy and Spain when they announced the joint con struction of advanced military jets, are very common in business. The project starts in the 80s and even though the deadline was the year 1997, in 2003 the project was still in process with a budget increase from 20 to 45 trillion dollars. Likewise, Whittaker, B. (1999) explains the failure rate of projects of Information Technology; a 2008 study in the US finds that customers cancel $31 \%$ of projects software before their completion. More than half of the projects cost on average a $189 \%$ of its original estimate, 250 billion dollars of expenses each year in the United States in developing IT applications.

According to Ika et al. (2012), underperforming projects and the dis appointment of stakeholders, especially final consumers, is the rule rather than the exception nowadays. According to World Bank statistics, failure of projects exceeds 50\%, whereas a study of the IEG (Independent Evaluation Group) states a failure rate of $39 \%$ of World Bank projects around the world in 2010.

According to Matta and Ashkenas (2003), economic theory could easily help to explain why firms, despite knowing that a high risk of fail ure exists in performing them, agree to design and implement innova tion projects. The benefits in the long term of successful projects are higher than the losses of failed projects. Project efficiency explains the profitability of having failed projects despite having other projects in the firm's portfolio Having a greater number of successful projects re sults in higher incomes for shareholders and greater learning for their employees.

Considering Matta and Ashkenas' (2003) results, this study aims to identify the organizational characteristics that make a firm successful in their innovation projects in Spain during the period 20082010 using the Spanish Community Innovation Survey (CIS).

Within the literature on variables for the analysis of success and fail ure of innovation projects, the use of the CIS is common because the CIS provides information on a large number of firms with different charac teristics for different countries.

Because all these surveys are conducted under the same methodol ogy proposed by the OECD, is possible to compare the results of studies based on these surveys for different countries.

Faria and Lima (2009) conduct an investigation about the two types of strategy that a firm can implement to their innovation projects: fo cusing on product and on process. Using data from the Portugal CIS in the period 19982000 and applying a Logit model to a sample of 821 firms, the authors conclude that organizational innovation leads firms to improve the performance of their innovation projects.

Polder et al. (2010) conduct a study on innovation's effect on pro ductivity, claiming that productivity increases process and organiza tional innovation. Likewise, Battisti and Stoneman (2010) conduct a research with UK CIS in 2004 and a sample of 16,383 companies seeking the complementarities between the two major types of innovation: or ganizational and technological (comprising product innovation, pro cess, machines, market, organization, management, and strategy). The authors clarify that these two groups are complementary but not substi tutes and suggest that technological innovation in the absence of orga nizational innovation cannot create competitiveness. Other authors find that this innovation capacity in firms tends to persist over time and that differences in levels of innovation among firms owe partially to the way firms address these differences (Mas Verdú et al., 2015).

Another significant research variable under study is the cooperation with different stakeholders participating in a project: partners, cus tomers, suppliers, etc. On this subject, Belderbos et al. (2004)conduct an investigation in Dutch companies using data from the CIS from 1996 and 1998 with data from 2056 companies. The authors determine whether different types of cooperative R\&D affect business growth in added value per employee and growth in sales of new products on the market per employee. Their results show that cooperation with sup pliers and partners has a significant effect on the growth of added value per employee. In this sense, Lhuillery and Pfister (2009) identify the characteristics contributing to 'failure of cooperation'.

The literature review shows that there exists a lack of analysis about the impact of organizational characteristics on the success of innovation projects. Several researches using CIS as the main data source conclude that organizational innovation is complementary to other types of inno vation and generally increases the likelihood of successful innovation.

To maintain consistency with previous investigations, the authors of this research work upon: the studies of Battisti and Stoneman (2010), Faria and Lima (2009) and Fiss (2011); and the formal structure of the Community Innovation Survey regarding selection and definitions of variables influencing the performance of innovation projects.

Hypothesis. Organizational innovation, degree of cooperation (with national and international partners), education level of employees, firm size, firm seniority, membership to a holding company and R\&D in vestment impact on performance of innovation projects.

\section{Data and method}

\subsection{Data}

This research uses data from the database Technology Innovation Panel (PITEC), including information since 2003, and aims to provide ad ditional information to databases on innovation activities in Spanish firms. This data panel builds on the Community Innovation Survey (CIS), which covers the time span between 2008 and 2010. The Spanish gross sample consists of 31,636 firms. The data gathering process consid ered the organizational innovation variable to collect the questionnaires in those firms. This measure leaves a final sample of $n=10,163$ firms ob servations. Thus, for this study the researchers consider the study of Greckhamer et al. (2013), who apply fsQCA to large data samples. These are the definitions of variables:

Organizational innovation, variable reflecting the implementation of organizational innovation during the period considered. 1 if the firm adopted at least one organizational innovation (knowledge management, workplace organization, or external relation) between 2008 and 2010. Degree of cooperation with national partners, variable reflecting the firm cooperation with other national firms/partners. Degree of cooperation with international partners, variable reflecting the firm cooperation with international firms/partners. Education, the share of employees with a doctoral degree (within the firm working in R\&D projects) operationalizes the education level of the workforce. Firm size, continuous variable specifying the number of employees in 2010. Firm seniority, con tinuous variable specifying the seniority of a firm designing, developing and delivering innovation projects. Holding company, variable indicating if firms belong to a holding company. R\&D investment, continuous vari able measuring the total investment in R\&D per employee.

\subsection{FsQCA in innovation research}

The fsQCA approach is an appropriate methodology to analyze com plex nonlinear relationships between variables (Ragin, 2008; Woodside, 2013). This type of analysis conceptualizes variables as combinations of attributes. By comparing cases, fsQCA allows a comprehensive under standing of how the various causes combine to produce a particular out come that suits causal complexity levels and identifies, in this case, the necessary and sufficient conditions of innovation project performance. This approach offers a practical way to organize the complex and inter dependent relations of cause effect that can explain the variation in the innovative behavior of firms (Fiss, 2011; Short et al., 2008). 
Analyzing the causal relationships in terms of set theoretic relations involves a number of new explanatory features that facilitate a better un derstanding of innovation processes and their effects on a firm. FsQCA identifies different configurations to achieve the same behavior innova tion. This method also accounts for equifinality, allowing multiple causal pathways that lead to the same outcome of interest (e.g., the performance of the innovation project). Therefore, fsQCA helps to differentiate be tween necessary and sufficient causal conditions for success in the perfor mance of innovation projects (Fiss, 2011). Whereas necessary conditions are attributes that every firm considered in the study shows, sufficient conditions describe combinations of attributes leading for themselves to the outcome of interest.

FsQCA works by progressing through several steps (Ganter \& Hecker, 2014). First, building a truth table. Second, reducing the number of rows in the truth table. Ragin (2006) recommends a minimum con sistency of 0.80 . Establishing necessary conditions should highlight cases that lead to the outcome. Conversely, cases where the outcome is not present are irrelevant, and are thus absent when testing proposi tions. Third, following a review of the truth table, an algorithm sim plifies combinations and minimizes solutions. The researcher must then determine how to handle logical remainders, implementing one of three alternative techniques. First, the parsimonious solution involves all simplifying assumptions, regardless of whether they include easy or difficult counterfactuals. Second, intermediate solution involves simpli fying assumptions by including easy counterfactuals. Third, complex so lution includes neither easy nor difficult counterfactuals.

The next step is to analyze if causal conditions belong to the core or to the peripheral configurations (parsimonious and intermediate solu tions). Core conditions are part of both parsimonious and intermediate solutions. Parsimonious solutions exclude peripheral conditions, which only appear in the intermediate solution. Outcome and conditions cor respond to the description and codification in Table 1 . The outcome (i.e., projsucc) is a dichotomous variable distinguishing if a firm has completed all the innovation projects launched in the period 20082010.

\section{Research findings}

This section presents the results from the analysis, explaining which conditions lead firms to the outcome (i.e., success in innovation project performance). The model for analysis is:

Projsucc $=f($ orginn, coop, coopint, educ, size, senior, holding, $R \& D)$.

The first step is to examine the conditions necessary for the outcome. Consistency does not exceed 0.8 for any condition (Table 2). Thus, no condition on its own assures success in innovation project performance. FsQCA method allows for analyzing combinations of conditions (causal configurations). Table 3 presents the results of the intermediate solu tion. This solution minimizes the combination, assuming that the condi tions of firm size, cooperation (with national and international partners) and holding company membership use lead to success in in novation projects. As Table 3 shows, analysis consistency is 0.81 , which indicates a sufficient relation between success in innovation pro ject performance and a certain subset of conditions.
Table 2

Analysis of necessary conditions for success in innovation projects.

\begin{tabular}{lll}
\hline & Consistency & Coverage \\
\hline Orginn & 0.52 & 0.72 \\
Coop & 0.46 & 0.69 \\
Coopint & 0.41 & 0.69 \\
Educ & 0.33 & 0.56 \\
Size & 0.72 & 0.84 \\
Senior & 0.31 & 0.42 \\
Holding & 0.31 & 0.43 \\
R\&D & 0.36 & 0.56 \\
\hline
\end{tabular}

The discussion of the results examines three solutions resulting from the analysis. These solutions appear in Table 3. Ragin (2008) recom mends a consistency threshold of 0.80 (all configurations comply with this threshold). Filled circles indicate above threshold levels of the re spective condition. Empty circles indicate below threshold levels. Blank cells indicate 'don't care' conditions.

The first configuration shows that a combination of organizational innovation, cooperation with international partners, and a large firm size is a sufficient condition for success in innovation project perfor mance. The second configuration implies that the combination of orga nizational innovation, cooperation with national partners, a large firm size, and holding company membership is also a sufficient condition for success in innovation project performance. The third configuration shows that a sufficient condition for success in innovation projects' per formance is the combination of organizational innovation and both na tional and international cooperation when the firm size is not large.

The results of this investigation align to other studies using CIS as data source (UK, Portugal, Netherlands, Germany), and confirm Faria and Lima (2009) conclusion about the relevance and impact of organi zational innovation on innovation projects, even for those projects fo cusing on product development and on processes. Just as Polder et al. (2010) state, a firm's competitiveness does not improve if technological innovation does not align with organizational innovation. This study confirms that investing in collaboration with different national and in ternational partners in the absence of organizational innovation cannot ensure the success of a project. Cooperative relationships with other partners have a significant effect on the growth of added value (Belderbos et al., 2004), but this cooperation should appear together with other variables such as firm size, a holding company membership, and components of organizational innovation, such as knowledge man agement and workplace organization. These configurations can im prove firm performance through the optimal performance of firms' innovation projects, and can guide the management board towards the establishment of strategic relationships with partners that meet cer tain characteristics to ensure the operational and strategic objectives of the firm.

\section{Conclusion}

This study examines organizational characteristics that affect inno vation projects' performance. The analysis uses fsQCA to identify

Table 1

Outcome conditions, description and codification.

\begin{tabular}{|c|c|c|}
\hline Outcome conditions & Description & Codification \\
\hline Outcome: Projsucc & Variable indicating if firms have completed all innovation projects during the period & Project success 1 Did not success 0 \\
\hline Orginn & Variable reflecting the implementation of organizational innovation during the period & Adopted org. Inn. 1 Did not adopt org. Inn. 0 \\
\hline Coop & Variable reflecting the firm cooperation with national firms/partners & Cooperation 1 No cooperation 0 \\
\hline Coopint & Variable reflecting the firm cooperation with international firms/partners & Int. cooperation 1 No int. cooperation 0 \\
\hline Educ & Continuous variable identifying the number of $\mathrm{PhD}$ within the firm working in R\&D projects & Fuzzy variable \\
\hline Size & Continuous variable specifying the number of employees & Fuzzy variable \\
\hline Senior & Continuous variable specifying the seniority of a firm developing innovation projects & Fuzzy variable \\
\hline Holding & Variable indicating if firms belong to a holding company & Holding 1 No holding 0 \\
\hline$R \& D$ & Continuous variable measuring the total investment in R\&D per employee & Fuzzy variable \\
\hline
\end{tabular}


Table 3

Configuration explaining organizational and business characteristics for success in innovation projects.

\begin{tabular}{|c|c|c|c|c|c|c|c|c|c|c|c|c|c|}
\hline \multirow[t]{2}{*}{ Solution } & \multicolumn{8}{|c|}{ Causal conditions } & \multirow[t]{2}{*}{ Raw coverage } & \multirow[t]{2}{*}{ Unique coverage } & \multirow[t]{2}{*}{ Consistency } & \multirow[t]{2}{*}{ Solution coverage } & \multirow[t]{2}{*}{ Solution consistency } \\
\hline & Orginn & Coop & Coopint & Educ & Size & Senior & Holding & $R \& D$ & & & & & \\
\hline 1 & $\bullet$ & & - & & $\bullet$ & & & & 0.15 & 0.05 & 0.82 & 0.64 & 0.81 \\
\hline 2 & $\bullet$ & $\bullet$ & & & $\bullet$ & & $\bullet$ & & 0.19 & 0.08 & 0.80 & & \\
\hline 3 & $\bullet$ & - & - & & O & & & & 0.26 & 0.06 & 0.81 & & \\
\hline
\end{tabular}

Filled circles indicate above-threshold levels of the respective condition. Empty circles indicate below-threshold levels. Blank cells indicate 'don't care' conditions. $\mathrm{n}=10,163$.

combinations of causes that lead to success in innovation projects per formance for Spanish firms. Organizational innovation, when the size of the firm is large and appears in combination with some kind of na tional or international cooperation, has an important effect on the suc cess of innovation projects. Furthermore, this study also demonstrates the effect of organizational innovation in the ultimate success of the projects, even when firms do not have a large size but combine both types of cooperation with other firms and partners. Thus, firms belonging to national and international networks facilitate performance and ultimate success of innovation projects in Spanish companies confirming that organizational innovation (as an adoption of knowl edge management, workplace organization, or external relation) is key and facilitates successful completion of the innovation projects.

Variables such as level of education of employees, expenditure on R\&D per employee, or the age of the firm have no direct effect on the success of innovation projects in Spanish companies.

A main implication of this study for practitioners is that practitioners can clearly identify the keys to success in planning, development, and launch of an innovation project. This ability can help firms, in the early stages of any innovation project, to identify the type of partner with whom to ally, to improve the management of human resources of the firm, and to determine to what extent the firm should invest in organi zational innovation.

This research has certain limitations, which may create opportuni ties for future investigations. For example, the research only addresses performance on innovation projects. Current research aims to obtain re sults for different types of projects (organizational, consulting, engi neering, business development), for different business sectors, even comparing same firms in different European regions.

\section{References}

Balachandra, R., \& Friar, J. (1997). Factors for success in R\&D projects and new product innovation: A contextual framework. IEEE Transactions on Engineering Management, 44(3), 276-287. http://dx.doi.org/10.1109/17.618169.

Battisti, G., \& Stoneman, P. (2010). How innovative are UK firms? Evidence from the fourth UK community innovation survey on synergies between technological and organizational innovations. British Journal of Management, 21(1), 187-206.

Belderbos, R., Carree, M., \& Lokshin, B. (2004). Cooperative R\&D and firm performance. Research Policy, 33, 1477-1492.

Belso Martínez, J. A., Molina-Morales, F. X., \& Mas-Verdu, F. (2013). Perceived usefulness of innovation programs for high-tech and low-tech firms. Management Decision, 51(6), 1190-1206.

Bloom, N., \& Van Reenen, J. (2010). Why do management practices differ across firms and countries? Journal of Economic Perspectives, 24(1), 203-224.

Cantner, U., Joel, K., \& Schmidt, T. (2011). The effects of knowledge management on innovative success: An empirical analysis of German firms. Research Policy, 40(10), 1453-1462.

Cheng, C. F., Chang, M. L., Li, C. S., \& Woodside, A. G. (2013). Theory and qualitative comparative analysis of configural paths to successful product innovation. Journal of Business Research, 66(12), 2561-2573.
Cooke-Davies, T. (2002). The real success factors on projects. International Journal of Project Management, 20(3), 185-190. http://dx.doi.org/10.1016/s0263-7863(01)00067-9.

Crossan, M. M., \& Apaydin, M. (2010). A multi-dimensional framework of organizational innovation: A systematic review of the literature. Journal of Management Studies, 47(6), 1154-1191.

Damanpour, F., \& Aravind, D. (2012). Managerial innovation: Conceptions, processes, and antecedents. Management and Organization Review, 8(2), 423-454.

Dilts, D., \& Pence, K. (2006). Impact of role in the decision to fail: An exploratory study of terminated projects. Journal of Operations Management, 24(4), 378-396. http://dx.doi. org/10.1016/j.jom.2004.12.001.

Dvir, D., Lipovetsky, S., Shenhar, A., \& Tishler, A. (1998). In search of project classification: A non-universal approach to project success factors. Research Policy, 27(9), 915-935. http://dx.doi.org/10.1016/s0048-7333(98)00085-7.

Faria, P., \& Lima, F. (2009). Firm decision on innovation types: Evidence on product, process and organizational innovation. Druid Summer Conference.

Fiss, P. C. (2011). Building better causal theories: A fuzzy set approach to typologies in organizational research. Academy of Management Journal, 54(2), 393-420.

Ganter, A., \& Hecker, A. (2014). Configurational paths to organizational innovation: Qualitative comparative analyses of antecedents and contingencies. Journal of Business Research, 67, 1285-1292.

García-Vega, M., \& López, A. (2010). Determinants of abandoning innovative activities: Evidence from Spanish firms. Cuadernos de Economía y Dirección de la Empresa, 13(45), 69-91. http://dx.doi.org/10.1016/s1138-5758(10)70024-4.

Greckhamer, T., Misangyi, V. F., \& Fiss, P. C. (2013). Chapter 3: The two QCAs: From a small-n to a large-n set theoretic approach. Configurational Theory and Methods in Organizational Research. 38. (pp. 49-75). Limited: Emerald Group Publishing.

Ika, L., Diallo, A., \& Thuillier, D. (2012). Critical success factors for world bank projects: An empirical investigation. International Journal of Project Management, 30(1), 105-116. http://dx.doi.org/10.1016/j.ijproman.2011.03.005.

Lhuillery, S., \& Pfister, E. (2009). R\&D cooperation and failures in innovation projects: Empirical evidence from French CIS data. Research Policy, 38(1), 45-57. http://dx.doi.org/ 10.1016/j.respol.2008.09.002.

Lovallo, D., \& Kahneman, D. (2003). Delusion of success. How optimism undermines executives' decisions. Harvard business review. (pp. 4279).

Mas-Verdú, F., Ribeiro-Soriano, D., \& Roig-Tierno, N. (2015). Firm survival: The role of incubators and business characteristics. Journal of Business Research, 68(4), 793-796. http://dx.doi.org/10.1016/j.jbusres.2014.11.030.

Matta, N., \& Ashkenas, R. (2003). Why good projects fail anyway. Harvard Business Review, 4872 .

Motohashi, K. (2005). University-industry collaborations in Japan: The role of new technology-based firms in transforming the national innovation system. Research Policy, 34(5), 583-594.

Pinto, J., \& Mantel, S. (1990). The causes of project failure. IEEE Transactions on Engineering Management, 37(4), 269-276. http://dx.doi.org/10.1109/17.62322.

Polder, M., Van Leeuwen, G., Mohnen, P., \& Raymond, W. (2010). Product, process and organizational innovation: Drivers, complementarity, and productivity effects. (MPRA Paper, n.23719).

Ragin, C. C. (2006). How to lure analytic social science out of the doldrums: Some lessons from comparative research. International Sociology, 21(5), 633-646.

Ragin, C. C. (2008). Redesigning social inquiry: Fuzzy sets and beyond. Chicago and London: University of Chicago Press.

Scott-Young, C., \& Samson, D. (2008). Project success and project team management: Evidence from capital projects in the process industries. Journal of Operations Management, 26, 749-766.

Short, J. C., Payne, G. T., \& Ketchen, D. J., Jr. (2008). Research on organizational configurations: Past accomplishments and future challenges. Journal of Management, 34(6), 1053-1079.

Whittaker, B. (1999). What went wrong? Unsuccessful information technology projects. Information Management \& Computer Security, 7(1), 23-29.

Woodside, A. G. (2013). Moving beyond multiple regression analysis to algorithms: Calling for adoption of a paradigm shift from symmetric to asymmetric thinking in data analysis and crafting theory. Journal of Business Research, 66, 463-472. 